review the part played by $\delta$ virus in exacerbating acute hepatitis B virus infection among 267 Irish drug abusers (p 1377). These authors saw $\delta$ virus markers among $75 \%$ of patients with fulminant hepatitis, $64 \%$ of those with severe hepatitis, and $36 \%$ of those with mild or moderate features, as compared with $14 \%$ of those who were asymptomatic, and suggest that concomitant delta infection worsens the clinical course.

Delta infection may be seen to be superimposed on chronic hepatitis B virus infection in all parts of the world. It has a higher morbidity and mortality than coprimary acute hepatitis $B$ virus and $\delta$ virus infection. In these circumstances delta infection may cause an acute hepatitis lasting for up to two months,,$^{25}$ or (in one to two thirds of cases) a prolonged course lasting from many months to years. ${ }^{25}{ }^{29} \mathrm{It}$ may also be fulminant and fatal: among Yucpa indians in Venezuela the mortality during acute illness was $17 \% .^{29}$ The continued presence of $\operatorname{IgM}$ anti- $\delta$ after superinfection is considered of prognostic importance since it is invariably found in hepatitis B surface antigen carriers in association with liver disease, and presumably reflects continuing intrahepatic synthesis of $\delta \mathrm{Ag} .{ }^{6}$

Though most patients who remain serologically positive for hepatitis B surface antigen and anti- $\delta$ have chronic active hepatitis or cirrhosis, it is still uncertain whether the illness in patients with both chronic hepatitis $B$ virus and chronic delta infection pursues an unusually aggressive course. Several recent clinicopathological studies with appropriate $\delta \mathrm{Ag}$ negative case controls suggest that this is the case. In Britain, for example, cirrhosis appears to be more common in chronic hepatitis $B$ virus carriers with ant $i-\delta$ than those without, and patients with anti- $\delta$ positive cirrhosis are younger than those with anti- $\delta$ negative cirrhosis, implying a more rapid progression of chronic liver disease. ${ }^{23}$ Similar age related findings have since been observed in Italy. ${ }^{30}$ Again in Italy children with hepatitis B surface antigen positive liver disease and anti- $\delta$ deteriorate more rapidly on both clinical and histological assessments over two to seven years compared with those who are anti- $\delta$ negative. ${ }^{31}$ By contrast, elsewhere in Italy the rates of worsening of the histological changes in the liver were similar among hepatitis B surface antigen carriers positive and negative for $\delta \mathrm{Ag}$, but here the biopsies showing intrahepatic $\delta \mathrm{Ag}$ also showed more severe liver disease initially than those without it. ${ }^{32}$

In view of the strong association between hepatocellular carcinoma and chronic infection with hepatitis B virus the possibility of a link between $\delta$ virus infection and primary liver cancer has come under scrutiny. Studies in South African blacks, ${ }^{33}$ Italians, ${ }^{34}$ Greeks, and Californians ${ }^{35}$ have failed to establish a connection. Conceivably, chronic delta infection may accelerate the disease process to such an extent that death ensues before hepatocellular carcinoma can develop.

Much remains to be learnt of the $\delta$ virus and its effects on man, and one question concerns its future spread. Here, nature and science have been kind to us: a vaccine already exists that will prevent the spread of delta infectionnamely, hepatitis B vaccine-and its liberal use in special risk groups seems eminently worth while, even more so than before.

Senior Lecturer in Infectious Diseases,

KarL G NichOLSON

Groby Road Hospital,

Leicester LE3 9QE

1 Rizzetto M, Canese MG, Arico S, et al. Immunofluorescence detection of new antigen-antibody system $(\delta /$ anti- $\delta$ ) associated to hepatitis B virus in liver and in serum of $\mathrm{HBsAg}$ carriers. Gut system $(\delta /$ anti- $\delta)$ assoc
$1977 ; 18: 997-1003$.
2 Rizzetto M. Canese MG. Gerin JL, London WT, Sly DL. Purcell RH. Transmission of the hepattitis B virus-associated delta antigen to chimpanzees. F Inf Dis 1980;141:590-602

Rizzetto .M. Hover B. Canese MG, Shih JW'-K, Purcell RH, Gerin JL. o Agent: asseciation of o antigen with hepatitis B surface antigen and RNA in serum of o-infected chimpanzees. Proc antigen with hepatitis B surface an
Vatl Acad Sci L'SA 1980;77:6124-8.

4 Rizzetto M. Shih JW'-K. Gerin JL. The hepatitis B virus-associated $o$ antigen: isolation from liver, development of solid phase radioimmunoassavs for $i$ antigen and anti- $\theta$ and partial haracterisation of o antigen. I Immunol 1980;125:318-24.

5 Bonino F, Hover B, Shih JW-K, Rizzetto M, Purcell RH, Gerin JL. Delta hepatitis agent: structural and antigenic properties of the delta-associated particle. Infect Immun 1984;43: $1000-5$

6 Smedile A, Lavarini C, Crivelli O, Raimondo G, Fassone M, Rizzetto M. Radioimmunoassay detection of $\operatorname{lgM}$ antibodies to the $\mathrm{HBV}$-associated delta $(\lambda)$ antigen: clinical significance in $\delta$ infection. F Med Virol 1982;9:131-8.

Shattock AG, Morgan BM, Peutherer J, Inglis JM, Fielding JF, Kelly MG. High incidence of delta antigen in serum. Lancet 1983;ii: 104-5.

8 Hov JF, Hansson BG, Dimitrakakis M, Gust I, Lucas CR. Delta agent infection in Melbourne. f Med Virol 1984;13:339-45.

9 Smedile A, Lavarini C, Crivelli O, et al. Epidemiological patterns of infection with the hepatitis B virus associated delta agent in Italy. Am J Epidemiol 1983;117:223-9.

10 Nordenfelt E, Hansson BG, Al-Nakib B, Al-Kandari S, Al-Nakib W. Frequency of delta infections in Kuwait. $\mathcal{F}$ Infect $D$ is 1983;148:768.

11 Dimitrakakis M, Gust ID. Delta infection in Pacific Islanders. Med f Aust 1984:141:197.

12 Smedile A, Dentico P, Zanetti A, et al. Infection with the delta (d) agent in chronic HBsA carriers. Gastroenterologv 1981;81:992.7.

13 Zanetti AR, Ferroni P, Magliano EM, et al. Perinatal transmission of the hepatitis $B$ virus and of the HBV-associated delta agent from mothers to offspring in northern Italy. $\mathcal{J}$ Med l'irol 1982;9:139-48.

14 Rizzetto M, Purcell RH, Gerin JL. Epidemiology of HBV-associated delta agent: geographical distribution of anti-delta and prevalence in polytransfused $\mathrm{HBsAg}$ carriers. Lancet 1980; $1215-9$.

15 Williams GV, Cossart YE. Delta associated hepatitis in Australia. Aust NZ J Med 1983;13:231-5. 16 Raimondo G, Smedile A, Gallo L, Balbo A, Ponzetto A, Rizzetto M. Multicentre study of prevalence of $\mathrm{HBV}$-associated delta infection and liver disease in drug addicts. Lancet 1982;

17 Caredda F, Rossi E, D'Arminio A, Farci P, Lavarini C. An outbreak of delta agent among a group of drug addicts and their close contacts. F Infect Dis 1984;149:286-7.

18 Anonymous. Leads from the MMWR d-Hepatitis-Massachusetts [Editorial]. FAMA 1984;252: 1666,1671 .

19 Ponzetto A, Cohen BJ, Vandervelde EM, Mortimer PP. Delta agent in Britain. Lancet 1983:ii: $1141-2$.

20 Shattock AG, Kelly MG, Fielding J, Arthurs Y. Epidemic hepatitis B with delta antigenaemia among Dublin drug-abusers. Ir J Med Sci 1982;151:334-8.

21 Hannson BG, Moestrup T, Widell A, Nordenfelt E. Infection with delta agent in Sweden introduction of a new hepatitis agent. $\mathcal{F}$ Infect Dis 1982;146:472-8.

22 Ponzetto A, Hoofnagle JH, Seeff LB. Antibody to the hepatitis B virus-associated delta-agent in immune serum globulins. Gastroenterology 1984;87:1213-6.

3 Weller IVD, Karaviannis P, Lok ASF, et al. Significance of delta agent infection in chronic hepatitis B virus infection: a study in British carriers. Gut 1983;24:1061-3.

24 Govindarajan S, Lee S-D, Tong MJ, et al. Prevalence of delta agent among Chinese in Taiwan and Los Angeles. F Med Virol 1984;14:33-7.

25 Moestrup T, Hansson BG, Widell A, Nordenfelt E. Clinical aspects of delta infection. Br Med 7 1983;286:87-90.

26 Papaevangelou G, Tassopoulos N, Roumeliotou-Karayannis A. Delta infection with hepatitis B. Lancet 1983;i:917.

Norkrans $G, H$ rmodsson $S$, Iwarson $S$. The delta agent in acute and chronic hepatitis $B$ infection in Sweden. Scand $\mathcal{Y}$ Gastroenterol 1983;18:675-8.

28 Tabor E, Ponzetto A, Gerin JL, Gerety RJ. Does delta agent contribute to fulminant hepatitis? Lancel 1983;i:765-6.

29 Hadler SC, De Monzon M, Ponzetto A, et al. Delta virus infection and severe hepatitis. Ann Inter Med 1984;100:339-44.

30 Craxi A, Raimondo G, Longo G, et al. Delt agent infection in acute hepatitis and chronic $\mathrm{HBsAg}$ carriers with and without liver disease. Gut 1984;25:1288-90

31 Farci P, Barbera C, Navone C, et al. Infection with the delta agent in children. Gut 1985;26:4-7.

32 Colombo $M$, Cambieri R, Rumi MG, et al. Long-term delta superinfection in hepatitis B surface antigen carriers and its relationship to the course of chronic hepatitis. Gastroenterology 1983;85:235-9.

33 Kew MC, Dusheiko GM, Hadziyannis SJ, et al. Does delta infection play a part in the pathogenesis of hepatitis B related hepatocellular carcinoma? Br Med J 1984;288:1727.

34 Raimondo G, Craxi A, Longo G, et al. Delta infection in hepatocellular carcinoma positive for hepatitis B surface antigen. Ann Intern Med 1984;101:343-4.

35 Govindarajan S, Hevia FJ, Peters RL. Prevalence of delta antigen/antibody in B-viral associated hepatocellular carcinoma. Cancer 1984;53:1692-4.

\section{Community care: planning mental health services}

In the wake of the Parliamentary Social Services Committee's second report on community care ${ }^{1}$ and some recent advice from the Chief Medical Officer on "That over used word Community!"' a timely conference on "mental health service planning" took place in London recently-organised jointly by the Royal College of Psychiatrists and the Department of Health and Social Security.

The meeting concentrated on problems associated with government mental health policies and priorities, with emphasis on the transition from hospital based to community based services. Inevitably much of the discussion concerned 
the closure of mental hospitals and mental handicap hospitals, the development of alternative mental health services, and the implications of these policies for patients, their families, and the wider community. Five main themes were tackled: the overall planning and organisation of services; the implementation of services for mental illness, the elderly mentally ill, and for the mentally handicapped; and the prospects for community care. Account was taken of the views of the British Association of Social Workers, the British Psychological Society, MENCAP, MIND, the Royal College of General Practitioners, and the Royal College of Nursing. A report based on the proceedings will be published in due course.

What, then, is the current state of community care? Many doctors have formed the impression that too often mentally disabled patients are discharged from hospital to community care which is inadequate. As the current initiatives proceed still more of these patients are going to need treatment in the community: so the crucial questions are how much care is being provided and how good is it?

The scope, extent, and impact of community care are difficult to estimate. Official figures (such as are given below) provide a starting point, but they may hide as much as they purport to disclose. Most importantly, they take virtually no account of the many people with psychiatric disorders already contained in the community-who represent further competition for whatever scarce mental health services and resources become available. Nevertheless, the key figures show that there were still 69000 inpatients in mental hospitals and units in 1983 and that there are about 120000 severely mentally handicapped people in England and Wales (though this estimate may be inaccurate). Furthermore, at present nine out of 10 mentally handicapped people live in the community, supported by parents, families, or in the care of voluntary bodies and in other non-institutional settings.

Against this background Lord Glenarthur, the parliamentary undersecretary for health, said he recognised the Social Services Committee's support for a policy of community care for mentally disabled people which "cannot and must not be done on the cheap," but he left the conference with two less than cheering, and unsurprising, messages: "money does not grow on trees" and "the government is committed to maintaining NHS funding at a level of $1 \%$ above inflation." On the first point, a few participants argued that sometimes money does grow on trees-in the shape of salable assets like mental hospitals and their surrounding lands. On the second, however, the conference clearly doubted the ability of the NHS to provide sufficient resources to fund mental health services that would be adequate during the transition and establishment of community care, bearing in mind the need, at the very least, to maintain the existing, unsatisfactory levels of provision and standards of clinical care.

In this context there was curiously little response at the conference to a recent proposal that the notion of unmet need for mental health services is a myth-based on the diffusion of traditional boundaries of mental health care, the diversion of resources from the long term mentally ill and their absorption by better functioning patients, and changes in the threshold for seeking help and assumptions of need. ${ }^{3}$ One psychologist did suggest that the emphasis in the discussions on replacing old services with new ones was misplaced. In his view what was required was an improvement on what was already available - an attitude which echoed the judgment of the Social Services Committee on the thorny issue of joint planning between health and social services: "The present priority must be to improve joint planning within the existing structural, financial, and personal constraints: in other words, to do the best with what we have got."

There are conflicting views on what might constitute the most appropriate models of care for the mentally disabled. The district general hospital is widely believed to provide a good local base for the development and provision of psychiatric services. The district general hospital psychiatric unit is acceptable to patients and their relatives; it may have financial advantages over the mental hospital; and it may be cheaper for society as a whole. Yet certain groups of patients will continue to require the equivalent of mental hospital care. One speaker concluded that acute admission wards should be sited in the grounds of district general hospitals, but in separately designed buildings, and that the care of long stay and demented patients should probably be in buildings outside the hospital. Psychiatrists providing services to the elderly seem to be confident that they could provide an entire service outside mental hospitals if they were provided with smaller units with a combination of inpatient and day care facilities-for example, on a district general hospital site.

The extent of the gap which exists between the principles and the practice of community care for the mentally handicapped is of particular concern. In certain regions plans make no provision for hospital beds for the mentally handicapped. One region is alleged to boast that no children with mental handicap need to be admitted to hospital. The policy of "normalisation" should, however, be interpreted realistically. Special facilities are likely to be required for the mentally handicapped who become mentally ill, behaviourally disturbed, or, indeed, elderly; and arrangements surely need to be made for various aspects of their general medical care.

One theme on which the conference agreed was that the funding of community developments for the mentally disabled should not be at the expense and to the detriment of hospital services for mental illness and mental handicap, which remain the main providers of residential care, particularly for the more resource intensive patient groups and for those who require specialised medical and psychiatric facilities.

The stated main long term aim of DHSS policy for mental health services is the creation of a comprehensive range of services provided within a district and in the context of a regional plan which takes account of district needs and resources and departmental priorities and policy. That must mean taking account in each district of the contribution of social, educational, housing, and employment resources and voluntary, statutory, and independent-including privateservices. Professor J K Wing added an important proviso: "the present ferment of change provides opportunities for weighing one kind of solution against another in order to determine which is more effective for meeting the particular problems of a particular community. If the alternative services are to be in place and shown to be working before large hospitals are closed, it is essential that multidisciplinary (including economic and administrative as well as clinical and social) evaluation be undertaken at a local level and on a scale hitherto not considered."

The pressure of policy and the call to action should not be allowed to overshadow the crucial need for evaluation. That can best be attempted, however, only after the harmonisation of policies and priorities among all agencies concerned. Another pressing need is for an increase both in the relevant health services research (for example, in local pilot projects) and in public debate. All this will require leadership, management, organisation, and planning of a high order: 
where these qualities are to be found is at present uncertain. As a first step, central government, regional and district health authorities, and local authorities should concentrate on developing, in consultation with other service providers and the consumers, "a pattern of service which will enable all those involved to work together and relate to the changing needs of mentally ill and mentally handicapped people and their families." The general practitioner and the primary care team have a critical part to play in these developments.

GREG WILKINSON

Honorary Lecturer

General Practice Research Unit,

Institute of Psychiatry,

London SE5 8AF

1 Parliamentary Social Services Committee. House of Commons. Community care with special reference to adult mentally ill and mentally handicapped people: second report from the Social Services Commitue. London: HMSO, 1985. (HC 13 I, II, III.)

2 Acheson ED. That over used word Community! Health Trends 1985;17:3.

3 Richmond A, Barry A. More and more is less and less: the myth of massive psychiatric need. $\mathrm{Br} F$ Psychiatry 1985; 146:164-8.

4 Department of Health and Social Security. Mental illness: policies for prevention, treatment, rehabilitation, and care. A note distributed within the NHS. London: DHSS, 1983.

\section{Endoscopic ultrasonography: a new look from within}

Standard techniques of ultrasound imaging through the skin surface have rapidly become of diagnostic importance, notably in the investigation of abdominal, cardiac, thyroid, and testicular diseases, and in obstetrics. The techniques are non-invasive and appear to be safe. Unfortunately there are physical limits to the quality of the image. The characteristics of external probes are a compromise, since the best resolution demands the highest frequencies, and these penetrate poorly. Furthermore, bone and gas are absolute barriers to transmission of a diagnostic beam. These two drawbacks have led to the development of invasive ultrasound probes, which may be placed directly in contact with internal organs. These are, for example, being used at open operation to scan the biliary tree, ${ }^{12}$ pancreas, ${ }^{12}$ and blood vessels, ${ }^{2}$ and through the rectum and urethra to scan the prostate and bladder. ${ }^{3}$

Endoscopic ultrasonography is a further extension of this principle. The ultrasound transducer is incorporated into the tip of a standard type of fibreoptic endoscope so that the mediastinum may be scanned from within the oesophagus and the abdominal organs examined from within the stomach and duodenum. Manufacturers have approached this goal in different ways, some using mechanically driven sector probes,${ }^{4}$ others electronic linear ${ }^{5}$ and phased array systems. ${ }^{6}$ All systems have had problems during development, but equipment for upper gastrointestinal application will be commercially available this year.

Endoscopic ultrasonography has many potential uses, and several centres have been assessing the prototype equipment enthusiastically. Most work in the thorax has concerned the heart. The technique has proved an acceptable alternative to conventional echocardiography in those patients (up to $10 \%$ ) who have a poor "echo window." The images are also complementary to conventional echocardiography as they are obtained from a unique orientation. Endoscopic ultrasonography gives particular detailed views of the posterior structures of the heart. Slight angulation of the transducer can provide complete tomographic cuts of the whole heart from one continuous "echo window"-the left atrium. The intra-atrial septum is viewed en face. Two studies have already claimed to show the superiority of endoscopic ultrasonography over conventional echocardiography in detecting atrial septal defects and assessing their size, with and without contrast injections. ${ }^{67}$ The detection rate of intraatrial thrombi (and other tumours) should be higher by endoscopic ultrasonography, since conventional echocardiography has a reported sensitivity for thrombus detection of only $59 \%$ in patients with rheumatic heart disease. ${ }^{8}$ The transoesophageal approach also allows continuous echocardiographic monitoring of left ventricular function during exercise ${ }^{9}$ and open heart surgery. ${ }^{10}$ It should prove useful in the prevention of air embolism associated with cardiac bypass by detecting air trapped in the ventricles before disconnecting the apparatus. ${ }^{11}$

Endoscopic ultrasonography provides superb views of the wall of the upper gastrointestinal tract. It has been used to stage oesophageal cancer ${ }^{12}$ and fully to document oesophageal varices. In the stomach the method has been used to define submucosal lesions, the depth and penetration of gastric ulcers and tumours, and spread to the local lymph nodes. ${ }^{1213}$

Scanning of organs outside the stomach requires considerable practice and skill..$^{514}$ The stomach is floppy and bears inconstant relationships with other organs. Scans are performed without direct endoscopic vision since air must be aspirated or replaced by water. Orientation may be helped by $x$ ray screening or by applying a conventional transducer to the abdominal wall and observing "crosstalk" between the two instruments. Passing the endoscope into the second part of the duodenum gives a more predictable orientation, but this is not always possible with some prototype instruments with relatively long rigid tips. ${ }^{5}$ is The pancreas may be viewed through the wall of the stomach and through the duodenum, and experts claim to be able to see most of the pancreas in almost all patients. ${ }^{16} 17$ The potential resolution is better than $1 \mathrm{~mm}$. Tiny liver metastases may be detected which cannot be seen on standard scans. Endoscopic ultrasonography is valuable in detecting the earliest changes of chronic pancreatitis and its findings are rarely equivocal in differentiating chronic pancreatitis from the normal organ or from pancreatic cancer.

The concept of being able to examine the entire mucosa of the upper gut, its walls, and all contiguous organs in one examination is a challenging dream. By the standards of conventional abdominal ultrasound the present equipment for endoscopic ultrasonography is primitive, but it will be improved substantially. These techniques are already spreading rapidly in Europe and Japan, but realistic clinical evaluation will take many years.

P B COTTON

Consultant physician department of gastroenterology

P J SHORVON

Senior registrar in radiology

W R LEES

Consultant radiologist

Middlesex Hospital,

London WIN 8AA

I Lane RJ, Glazer G. Intra-operative B-mode ultrasound scanning of the extra hepatic biliary system and pancreas. Lancet 1980;ii:334-7.

2 Sigel B, Coelho JCU, Machi J, et al. The application of real-time ultrasound imaging during surgical procedures. Surg Gymecol Obstet 1983;157:33-7. 